\title{
PENTINGNYA VAKSINASI DI MASA PANDEMI
}

Kilmatuna Hadani

\author{
IIK STRADA INDONESIA
}

\section{kilmatuna.hadani14@gmail.com}

\begin{abstract}
Abstrak
Pada tanggal 31 Desember 2019, dilaporkan terdapat 27 kasus pneumonia dengan etiologi yang tidak diketahui di Kota Wuhan, provinsi Hubei di Cina (Sun et al., 2020). Pada 11 Februari 2020, WHO secara resmi menyebut penyakit yang dipicu oleh 2019-nCoV sebagai Penyakit Virus Corona 2019 (COVID-19). Pada 30 Januari 2020, WHO mendeklarasikan wabah COVID-19 di Cina sebagai Kedaruratan Kesehatan Masyarakat yang Meresahkan Dunia (Public Health Emergency of International Concern, PHEIC) ini meandakan COVID-19 sebagai ancaman global dunia. Penelitian ini menggunakan metode review article. Sumber data penelitian ini berasal dari literatur yang diperoleh melalui internet berupa hasil penelitian dari publikasi jurnal Internasional. Vaksin adalah cara yang paling efektif dan ekonomis untuk mencegah penyakit menular. Pengembangan afektif terhadap infeksi SARS-CoV-2 sangat diperlukan. sejauh ini lebih dari 40 perusahaan farmasi dan lembaga akademis di seluruh dunia telah meluncurkan program pengembangan vaksin mereka melawan SARS-CoV-2. Vaksin mRNA memiliki keunggulan dibandingkan vaksin konvensional lainnya, dengan tidak adanya integrasi genom, respon imun yang berkembang, perkembangan yang cepat dibandingkan jenis vaksin lainnya, dan kemampuan memproduksi antigen multimeric. Namun sejauh ini belum ada vaksin mRNA yang masuk ke pasaran, sehingga mungkin diperlukan lebih banyak waktu dalam penetapan standar kualitas dan evaluasi keamanan vaksin.
\end{abstract}

\section{Latar Belakang}

Vaksinasi dasar yang lengkap merupakan faktor penting dalam proses perkembangan anak. Namun, masih banyak masyarakat yang meragukan maupun kurang paham akan pentingnya vaksinasi dasar. Beberapa kelompok masyarakat memiliki pengetahuan yang kurang mengenai penyakit yang dapat dicegah dengan vaksinasi sehingga mereka meremehkan vaksinasi. Selain itu, adanya isu-isu kontradiktif yang mengatakan vaksinasi membawa dampak negatif seperti kemandulan, AIDS dan autisme terkadang didengar di kalangan masyarakat. Padahal, menurut data 
WHO, vaksinasi merupakan alat yang terbukti mengontrol dan mengurangi penyakit infeksius yang mengancam hidup, dengan estimasi 2 sampai 3 juta kematian per tahunnya yang telah dicegah oleh vaksinasi.

Vaksinasi dasar merupakan usaha dalam bidang kesehatan untuk melakukan pencegahan timbulnya penyakit mematikan yang sulit untuk diobati pada bayi dan anakanak. Maka itu, program vaksinasi dasar di Indonesia diberikan secara gratis dari pemerintah melalui puskesmas atau posyandu. Vaksinasi dasar yang dimaksud adalah hepatitis B, DPT (difteri, pertussis, dan tetanus), polio, campak, BCG (Bacille Calmette Guerin). Penyakit - penyakit yang tercakup dalam vaksinasi dasar tersebut cukup sering ditemukan dan mempunyai tingkat mortalitas yang tinggi dan prognosis yang cenderung buruk, sehingga ada kemungkinan perbedaan tumbuh kembang antara anak yang tervaksinasi dan yang tidak. Tumbuh kembang adalah proses yang berjalan terusmenerus sejak pembuahan hingga dewasa.

Pertumbuhan merupakan perubahan pada ukuran, jumlah, tingkat sel, yang dapat diukur melalui massa (berat badan) dan/atau panjang. Perkembangan adalah perubahan pada kemampuan atau keterampilan menuju struktur dan fungsi tubuh yang lebih kompleks sebagai hasil dari proses pematangan. Keduanya tidak dapat dipisahkan dan saling terkait. Pemilihan kelompok usia anak berusia satu sampai tiga tahun ditetapkan atas dasar pertimbangan proses perkembangan otak yang paling pesat selama kehidupan. Selain itu, pada usia tersebut anak akan lebih banyak berinteraksi di lingkungan rumah. Interaksi yang terbatas di lingkungan rumah diharapkan dapat menyingkirkan faktor asupan gizi yang kurang seimbang karena konsumsi makanan yang tidak diawasi orang tua, maupun makanan yang kurang higienis di lingkungan sekolah. Di Guinea-Bisseau, suatu riset vaksinasi tambahan campak pada usia 4.5 bulan yang dilakukan lebih awal dari yang dianjurkan telah diteliti. Vaksin tersebut tidak hanya terbukti mengurangi mortalitas, tapi juga meningkatkan pertumbuhan (diukur dari lingkar lengan). Pada penelitian lain di Roma, anak imigran yang mengalami keterbelakangan pertumbuhan diketahui bahwa 3.4\% dari anak di atas usia 6 bulan dalam 1,310 sampel penelitian tidak pernah mendapatkan vaksinasi. Penelitian di atas telah dilakukan untuk mendapatkan keterkaitan vaksinasi dengan tumbuh kembang. Meskipun itu, kedua penelitian tersebut masih menimbulkan keraguan karena cara dan hasil dari keduanya belum menyimpulkan relasi langsung antara vaksinasi dengan tumbuh kembang pada anak.

\section{Kasus atau Masalah}


Hingga sampai saat ini virus corona belum juga berakhir. Guna menekan kasus yang terus bertambah, pemberian vaksin COVID-19 mulai dilakukan. Pemerintah pun menganjurkan agar semua orang mendapatkannya. Sejak vaksin COVID-19 tiba di Indonesia, tidak sedikit masyarakat yang belum setuju akan anjuran pemerintah untuk menjalani vaksinasi COVID-19. Padahal, pemberian vaksin ini sangatlah penting, bukan hanya untuk melindungi masyarakat dari COVID-19, tetapi juga memulihkan kondisi sosial dan ekonomi negara yang terkena dampak pandemi. Vaksinasi atau imunisasi bertujuan untuk membuat sistem kekebalan tubuh seseorang mampu mengenali dan dengan cepat melawan bakteri atau virus penyebab infeksi.

Tujuan yang ingin dicapai dengan pemberian vaksin COVID-19 adalah menurunnya angka kesakitan dan angka kematian akibat virus ini. Meskipun tidak 100\% bisa melindungi seseorang dari infeksi virus Corona, vaksin ini dapat memperkecil kemungkinan terjadinya gejala yang berat dan komplikasi akibat COVID-19. Selain itu, vaksinasi COVID-19 bertujuan untuk mendorong terbentuknya herd immunity atau kekebalan kelompok. Hal ini penting karena ada sebagian orang yang tidak bisa divaksin karena alasan tertentu.Orang yang tidak dianjurkan untuk menerima vaksin atau tidak menjadi prioritas untuk vaksin COVID-19 antara lain anak-anak atau remaja berusia di bawah 18 tahun dan orang yang menderita penyakit tertentu, misalnya diabetes atau hipertensi yang tidak terkontrol. Jadi, dengan mendapatkan vaksin COVID -19 , anda tidak hanya melindungi diri sendiri, tapi juga orang-orang di sekitar Anda yang belum memiliki kekebalan terhadap virus Corona.

\section{Tinjauan Pustaka}

Vaksin COVID-19 memang dapat membawa banyak manfaat dengan melindungi kita dari infeksi virus Corona. Namun, perlu diketahui bahwa vaksin ini tidak diberikan kepada orang yang sedang sakit berat atau sudah terinfeksi virus Corona. Jadi, pastikan untuk selalu mempertahankan daya tahan tubuh kita, baik sembari menunggu giliran untuk diberikan vaksin maupun setelahnya. Hal ini karena dengan imunitas tubuh yang kuat, kita tidak akan mudah sakit sehingga kebugaran tubuh tetap terjaga. Beberapa cara untuk meningkatkan daya tahan tubuh adalah mengonsumsi makanan bergizi, rutin berolahraga, mengelola stres dengan baik, serta beristirahat yang cukup. Selain caracara tersebut, kita juga bisa mengonsumsi produk herbal yang dapat meningkatkan imunitas tubuh. Beberapa jenis herba yang kandungannya dipercaya mampu memperkuat daya tahan tubuh adalah:

* Meniran hijau, karena mengandung zat imunomodulator untuk memperbaiki 
sistem kekebalan tubuh yang lemah.

* Daun kelor, karena mengandung antioksidan dan terbukti dapat meningkatkan daya tahan tubuh.

* Kunyit, karena mengandung banyak antioksidan untuk melindungi tubuh dari efek buruk radikal bebas dan memperkuat imun.

Di samping menjaga daya tahan tubuh, kita perlu tetap menerapkan protokol kesehatan, baik selama menunggu giliran untuk divaksin maupun setelah mendapatkan vaksin. Sebisa mungkin juga hindari bepergian ke luar rumah atau berkumpul dengan orang banyak. Vaksin COVID-19 diharapkan bisa menjadi solusi untuk menyudahi pandemi yang telah memakan banyak korban jiwa serta melumpuhkan aktivitas masyarakat, dan partisipasi kita dalam program vaksinasi ini akan sangat membantu pemulihan kondisi negara kita.

\section{Pembahasan}

Vaksinasi Covid-19 memiliki banyak manfaat, tidak hanya untuk diri sendiri tetapi juga untuk banyak orang. Vaksin Covid-19 aman dan halal, hal ini disampaikan oleh Komisi Fatwa MUI Pusat bahwa sudah memberikan fatwa bahwa vaksin Covid-19 halal dan suci. Oleh karenanya, meskipun masih banyak beredar isu atau hoax mengenai vaksin yang belum jelas kebenarannya, masyarakat tidak perlu ragu dan khawatir untuk melakukan vaksinasi Covid-19 guna kepentingan bersama.

Seperti vaksin pada umumnya, vaksin Covid-19 berpotensi mengakibatkan efek samping bagi penerimanya. Efek samping seperti lengan pegal, meriang, mual dan sebagainya sangat wajar dialami setelah menerima vaksin. Hal tersebut pertanda bahwa vaksin sedang bekerja dan tubuh sedang membangun antibody untuk melawan virus yang mungkin akan menginfeksi di masa yang akan datang. Efek samping biasanya berlangsung selama kurang lebih 3 hari saja dan akan hilang dengan sendirinya. Namun, untuk beberapa kasus vaksin dapat menyebabkan Kejadian Ikutan Pasca Imunisasi (KIPI). KIPI berbeda dengan efek samping biasa, sehingga perlu penanganan khusus bagi yang mengalaminya.

KIPI dapat terjadi dengan tanda atau kondisi yang berbeda-beda setiap orangnya. Mulai dari gejala efek samping ringan hingga reaksi tubuh yang serius seperti alergi yang parah terhadap kandungan vaksin. Gejala KIPI yang ringan dapat bersifat lokal berupa rasa yang nyeri, 
kemerahan serta pembengkakan di area yang mengalami infeksi setelah diberikan imunisasi. KIPI ringan biasanya terjadi sesaat setelah disuntik vaksin dan dapat membaik dengan cepat setelah diberikan pengobatan untuk mengurangi gejala. Sedangkan KIPI berat cenderung langka terjadi, pada umumnya disebabkan oleh respon system imun terhadap vaksin dan menyebabkan reaksi alergi berat terhadap bahan vaksin, menurunkan trombosit, menyebabkan kejang, dan hipotania. Semua gejala KIPI berat dapat diatasi dan sembuh secara total tanpa adanya dampak jangka panjang.

Terlepas dari berbagai risiko yang dapat ditimbulkan, proses vaksinasi merupakan prosedur yang aman. KIPI merupakan suatu kasus yang dipengaruhi oleh berbagai faktor, misalnya kondisi dan kesehatan seseorang serta proses vaksinasi itu sendiri. Gejala KIPI yang benar-benar disebabkan substansi vaksin cenderung ringan dan dapat hilang dalam waktu yang singkat. KIPI juga merupakan kasus yang jarang terjadi dan kebanyakan tidak membahayakan. Risiko munculnya KIPI masih lebih ringan dibandingkan risiko terjangkitnya penyakit serius yang tentu lebih mengancam nyawa.

\section{Kesimpulan}

> Diplomasi pemenuhan kebutuhan vaksin COVID-19 melakukan penjajakan kerjasama dengan negara dan badan internasioanl. Bilateral dan Multilateral.

> Kementrian Kesehatan telah menyiapkan peraturan SDM, administrasi, logistik, jaringan fasyankes dan sistem monev untuk pelaksanaan vaksinasi COVID-19.

> Tenaga kesehatan merupakan salah satu ujung tombak dalam hal penanggulangan COVID-19 sehingga perlindungan terhadap tenaga kesehatan menjadi hal penting yang perlu diperhatikan.

> Vaksinasi saat ini sudah mulai dilaksanakan namun penerapan protokol kesehatan tetap menjadi hal utama yang perlu dilakukan oleh seluruh masyarakat termasuk tenaga kesehatan.

VI. Daftar Pustaka

http://rsud.sampangkab.go.id/berita/detail/pentingnya-vaksinasi-di-masa-pandemicovid19

http://ojs3.unpatti.ac.id/index.php/moluccamed 


\section{https://corona.jakarta.go.id/id/artikel/mengupas-kipi-dan-efek-samping-vaksin-covid-}

$\underline{19}$

\section{https://dinkes.surakarta.go.id/pentingnya-vaksinasi-covid-19/}

Sodik, M. A., \& Akoit, A. (2016). Looks Personal Hygiene Of StudentSenior High Scholl With The Herpes Disease.Journal of Global Research in PublicHealth,1(1), 73-78.

Sodik, M. A., \& Saheri, M. (2019). Corelation Study Between Knowledge,Attitude Toward Tenaager's Sexual Beahaviour Who Was Domiciled In EnglishVillage.Journal of Global Research in Public Health,4(2).

TAHIN, M. W., \& Sodik, M. A. (2021). Pengaruh Merokok Bagi RemajaTerhadap Perilaku dan Pergaulan Sehari-hari.

Attoriq, S., \& Sodik, M. A. (2018). Pencegahan Dan Pengendalian InfeksiTerkait Pelayanan Kesehatan Di Lahan Praktik.

TAHIN, M. W., \& Sodik, M. A. (2021). Pengaruh Merokok Bagi RemajaTerhadap Perilaku dan Pergaulan Sehari-hari.

Sodik, M. A., Suprapto, S. I., \& Pangesti, D. (2013). Faktor-Faktor YangBerhubungan Dengan Pelaksanaan Pelayanan Prima Pegawai Di Rsui OrpehaTulungagung.STRADA Jurnal IImiah Kesehatan,2(1), 24-32.

Tule, A. R., Siyoto, S., Dwianggimawati, M. S., \& Sodik, M. A. (2018). TheAnalysis Factors Affecting Interest In Medication Of Receipt Help Aid BpjsParticipant In Balowerti Public Health Center Kediri City.Journal of GlobalResearch in Public Health,3(1), 6875.

Oktoriani, E. N., Sutrisno, J., Mayasari, E., \& Sodik, M. A. (2018). Analysisof medical record complete flexibility to complete claims of health BPJS RSBaptis Kota Batu.Journal of Global Research in Public Health,3(1), 46-53.

Sodik, M. A., Astikasari, N. D., Fazrin, I., Chusnatayaini, A., \& Peristiowati,Y. (2018). Dental health child with retardation mental and parents behavior.IndianJournal of Physiotherapy and Occupational Therapy-An InternationalJournal,12(4), 278-282. 